\title{
The legacies of the Royal Institution
}

Frank A. J. L. James

Citation: Physics Today 71, 8, 36 (2018); doi: 10.1063/PT.3.3996

View online: https://doi.org/10.1063/PT.3.3996

View Table of Contents: http://physicstoday.scitation.org/toc/pto/71/8

Published by the American Institute of Physics

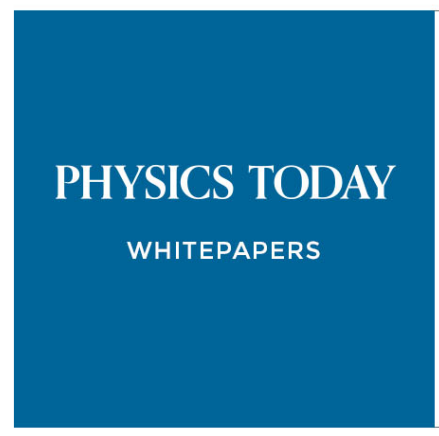


Frank A. J. L. James is a professor in the department of science and technology studies at University College London and professor of the history of science at the Royal Institution in London. He is the editor of the six-volume collection The Correspondence of Michael Faraday (1991-2012) and the author of Michael Faraday: A Very Short Introduction (2010).
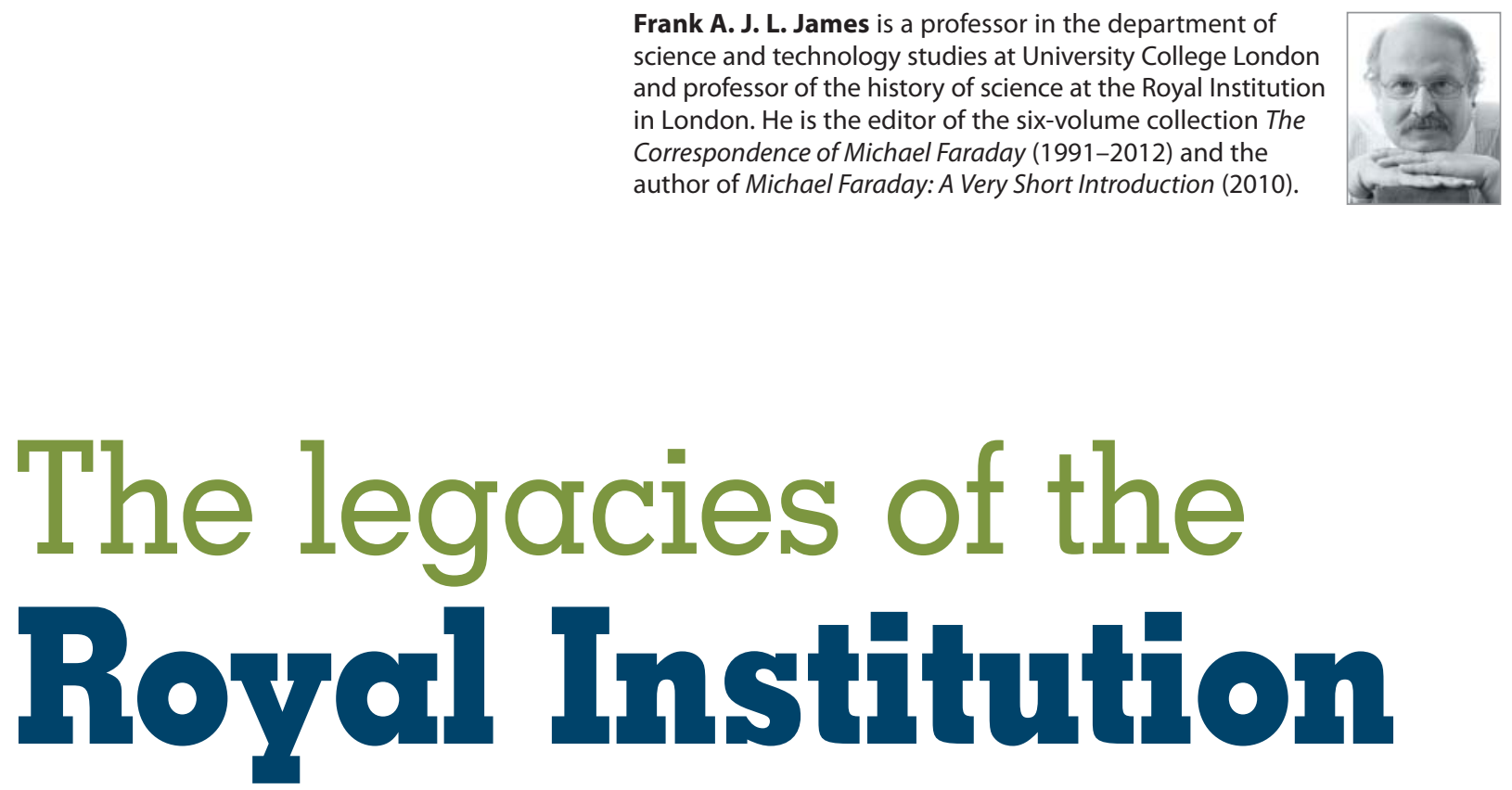

Frank A. J. L. James

The London-based scientific organization has left its mark on everything from electrochemistry and molecular biology to lighthouse design, and it has been a leading innovator in science communication for more than 200 years.

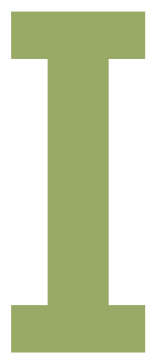

$\mathrm{n}$ the heart of the fashionable and wealthy Mayfair district of central London, behind Corinthian columns, the Royal Institution of Great Britain continues in the same building that it has always occupied (see figure 1) - no small achievement for an organization founded in the 18th century. ${ }^{1}$ The scientific knowledge that has flowed out of the Royal Institution since its founding more than two centuries ago has had crucial impacts on the development of society and culture throughout the world. For 70 years it possessed the best-equipped laboratory in Britain and one of the best in Europe. From it emerged scientific discoveries in physics and chemistry that radically altered the way we think about the world. and men of science gathered at Banks's home with a shared goal: To create, as they put it, "a Public Institution for diffusing the Knowledge and facilitating the general Introduction of useful Mechanical Inventions and Improvements, and for teaching by courses of Philosophical Lectures and Experiments, the Application of Science to the Common Purposes of Life." 2

Its establishment took place against the backdrop of the increasing industrialization that had occurred in Britain during the preceding century and a war

The Royal Institution was founded at a meeting held on 7 March 1799 in the London house of Joseph Banks (1743-1820), president of the Royal Society of London for 42 years from 1778. A mixed group of landowners, aristocrats, politicians, businessmen, military officers, with France, then in its sixth year. The war, which would continue for 16 more years, meant that Britain had restricted access to continental markets and was forced to rely on its own resources.

To help overcome that problem, Banks and the others 


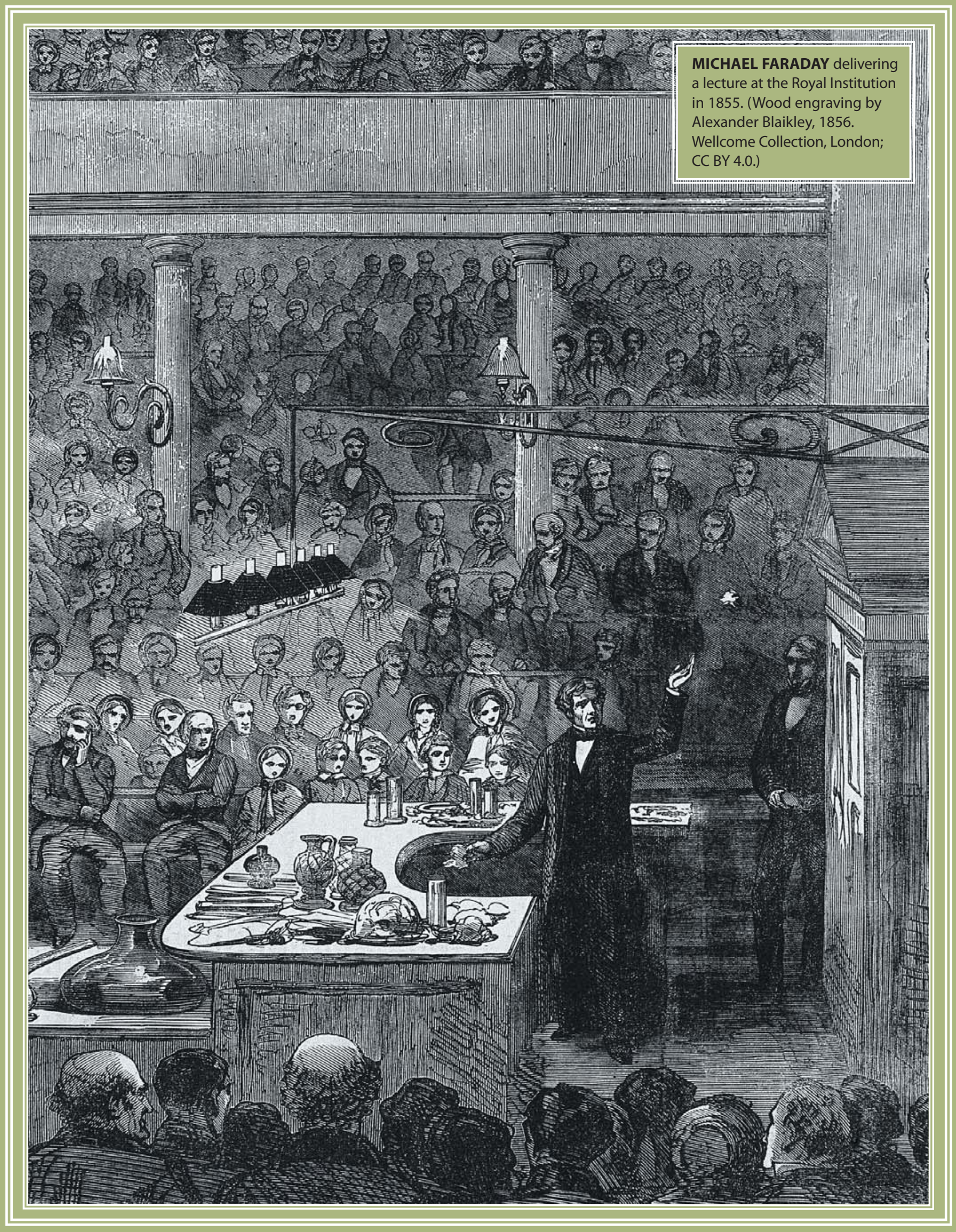


envisaged that the Royal Institution would provide, through lectures, access to scientific and technical knowledge to a lay audience of wealthy and aristocratic listeners. The hope was that those audience members would leave the lecture hall and go on to apply that knowledge for practical purposes-for example, in agricultural improvement, industrialization, and the consolidation of the British Empire.

By the initial meeting in Banks's house, 58 gentlemen had agreed to contribute 50 guineas each to be a proprietor of the new institution. That donation, a substantial sum, would buy the services of a good cook for a year; only the really wealthy could become proprietors. There were also life and annual subscribers to lectures who paid significantly less but had no role in running the institution. Women soon joined at all levels, but some outside the Royal Institution saw that as evidence that it was not a serious organization.

The first thing that needed to be done was to acquire a building. By the summer of $1799, £ 4850$ had been paid for the lease of 21 Albemarle Street-a lease that next expires in 3921. During the 18th century, the building had been a gentleman's town house, so it had to be converted to add lecture theaters, laboratories, libraries, display areas, and offices. The famous semicircular theater, which could hold more than 1000, was constructed at the northern end of the building and became operational at the start of 1801.

\section{The first professors: Garnett, Young, and Davy}

On 11 March 1800, Thomas Garnett (1766-1802), the recently appointed professor of chemistry at the Royal Institution, delivered its first lecture in a temporary room. Garnett had made his reputation as an itinerant lecturer. He was a professor of chemistry at the Andersonian Institution in Glasgow before moving to the Royal Institution.

Garnett's long experience as a lecturer put him into conflict with the Royal Institution's Managers, a committee elected by the proprietors from among themselves. They took the view, not shared by Garnett, that he should seek their permission before publishing details of his lectures. It seems that as early as January 1801, moves were being made to force him out. In the spring Humphry Davy (1778-1829) was appointed assistant lecturer; when Garnett resigned over a salary dispute, Davy became the new professor of chemistry. Shortly afterwards Thomas Young (1773-1829) was appointed professor of natural philosophy. It was in the syllabus for his Royal Institution lectures that Young first published his discovery of the interference of light. However, Young, even by his own account, was a fairly uninspiring lecturer and did not last long. ${ }^{3}$

Such was not the case with Davy. Born in Penzance in the far west of Britain, Davy was a former apothecary's apprentice and the son of a yeoman farmer. ${ }^{4}$ In October 1798 he became

superintendent of the Medical Pneumatic Institution in Bristol with the help of his patronage network. While in Bristol, Davy discovered the remarkable physiological properties of nitrous oxide, which led to its being popularly called laughing gas. Its effects were splendidly portrayed in a famous caricature by James Gillray, depicting Garnett administering the gas to the Royal Institution's treasurer John Hippisley with somewhat unfortunate results, while a slightly demonic Davy watches with a pair of bellows poised for further action (see figure 2).

Davy to some extent subverted the original intentions of the Royal Institution. ${ }^{5}$ Most notably, he made scientific research one of its key features - not a mission envisaged by its founders. At the Royal Institution, Davy conducted extensive electrochemical researches and developed the earliest coherent theory of electrochemical action. In the process he discovered several chemical elements, including sodium and potassium. He traveled widely throughout Europe collecting minerals and visiting as many volcanoes as he could to formulate a theory of geochemical action, something that he didn't quite manage.

But Davy did continue - albeit on his own terms - with the Royal Institution's original utilitarian agenda, as exemplified by his spectacularly successful invention of the gauze safety lamp for coal mines in the mid 1810s. His attempts to protect the copper bottoms of ships electrochemically, unfortunately, were less successful. ${ }^{6}$

Despite his record of invention, Davy did not lecture much on utilitarian topics. He found that what the Royal Institution's audience wanted were spectacular-preferably explosivelectures, whether or not the subjects were practical in nature. From 1801 until his marriage to a wealthy widow in 1812 (which enabled him to retire from lecturing at age 33), Davy became the most popular lecturer in London. It was therefore not in the institution's interests to discipline him as they had done with 


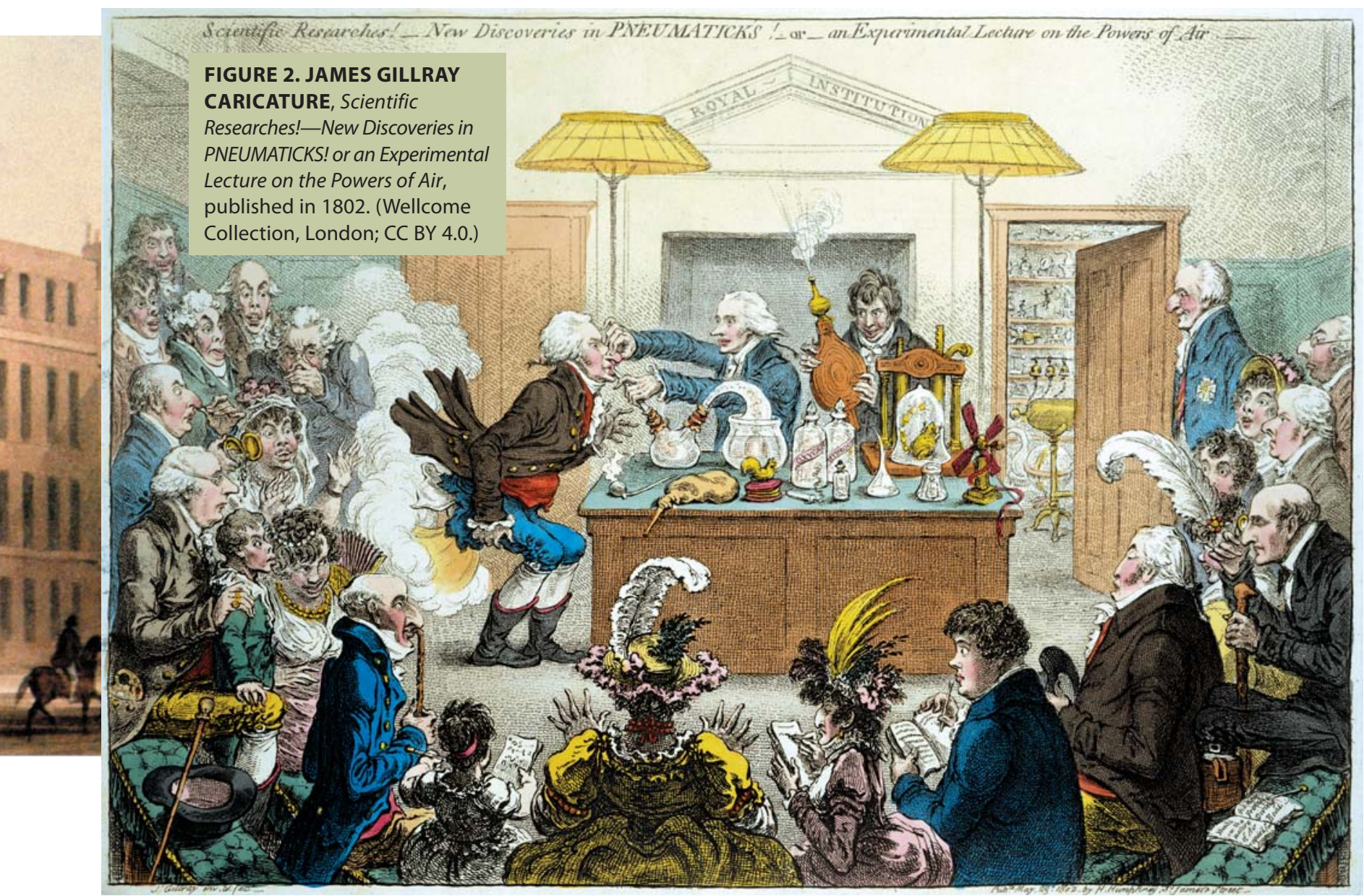

Garnett. Furthermore, Davy attracted a strong female audience; more than half of those who attended his lectures were women. Female auditors included Jane Marcet, who in 1806 published her hugely popular Conversations on Chemistry stemming from Davy's lectures.

\section{Faraday}

One of Marcet's readers was Michael Faraday (1791-1867), an apprentice bookbinder and the son of a blacksmith. Faraday, like his parents, was a member of the Sandemanian Church, a small literalist sect of Christianity to which he remained fully committed throughout his life. ${ }^{7}$ As a non-Anglican, he could not attend either of the two English universities at the time, since students at both Oxford and Cambridge were required to sign the Church of England's Thirty-Nine Articles of Religion.

Instead, he served a seven-year apprenticeship in London. By the time his apprenticeship ended in 1812, he had read Marcet, had attended scientific lectures at the City Philosophical Society, and had evidently decided to become a chemist. By good fortune, he was given tickets to attend Davy's last four lectures. He took neat and detailed notes, presented them to Davy, and asked for a job (see figure 3).

Faraday was appointed laboratory assistant at the Royal Institution in March 1813. He worked there for the remainder of his life, and he rose through the ranks to become superintendent of the house in 1821 and director of the laboratory in 1825. In 1833 the Fullerian Professorship of Chemistry was created especially for him by an eccentric philanthropist, John Fuller.
At the Royal Institution, Faraday continued the triple agenda that Davy had established of research, lecturing, and providing advice to the state and its agencies. After Danish savant Hans Christian Oersted discovered electromagnetism in 1820, Faraday turned his attention to that subject. The following year he discovered electromagnetic rotations, the principle behind the electric motor. Ten years later, in August 1831, Faraday discovered electromagnetic induction and made the first transformer and generator to produce electric current from the movement of a magnet in a coil of wire. The originals of both those devices are on display in the Faraday Museum of the Royal Institution, along with about a thousand other objects. The impact of those discoveries is still felt today. No matter what primary source of energy is used, all power stations generate electricity based on the fundamental principles Faraday discovered in his basement laboratory in 1831.

Faraday then turned his attention to electrochemistry and in 1833 established his laws of electrolysis. Along with several classical scholars, he developed the nomenclature of electrochemistry, including terms like electrode, anode, cathode, and ion. In 1836 Faraday built a cage, a 12-foot cube covered in metal wires, for which only the Royal Institution's lecture theatre was large enough to provide the necessary space. The results of the experiments he made in the cage enabled him to argue that electricity was a force rather than an imponderable fluid, as had been thought up to that time.

In 1845 Faraday discovered that light was affected by magnetism and that all matter, not just iron, possessed magnetic 
properties. Those experimental discoveries allowed him to formulate his field theory of electromagnetism, which laid the theoretical foundations for electrical communication. Faraday's younger contemporaries William Thomson (later Lord Kelvin) and James Clerk Maxwell later mathematized that theory, and it remains one of the cornerstones of classical physics.

Faraday also gave extensive advice to the British state. For example, in 1836 he was appointed scientific adviser to Trinity House, the English and Welsh navigation authority. A full 17\% of his surviving letters dealt with lighthouse matters. In his advisory role, Faraday helped make great improvements to the lighthouse service. He developed a new oil lamp, which was also used in other buildings such as the new Houses of Parliament and Buckingham Palace, and oversaw the experimental introduction of electric light at the South Foreland Lighthouse on the Kent coast in southeastern England.

Faraday's other major pieces of work for the state included conducting, with geologist Charles Lyell, the 1844 inquiry into an explosion at Haswell Colliery, County Durham, which killed 95 men and boys. ${ }^{8}$ He advised the Admiralty from 1829 through the Anglo-French war with Russia in the mid 1850s, when he suggested that one of the proposed plans of attack against Russia's Baltic naval fortress of Kronstadt would probably fail. Between 1830 and 1852, he taught chemistry at the Royal Military Academy. So extensive was his work for the state and its agencies that one can imagine the cry "send for Faraday" going up in Westminster or Whitehall when the government required scientific expertise.
At the Royal Institution, Faraday was instrumental in founding and sustaining two series of lectures that continue to this day. He started the Friday Evening Discourses in 1825; more than 3000 discourses have been delivered since, and they have covered a broad range of both scientific and nonscientific subjects. They have also been the stage for major scientific announcements, including William Henry Fox Talbot's invention of photography in 1839, and J. J. Thomson's discovery of the fundamental particle later called the electron in 1897.

The other series that Faraday made famous was the Christmas Lectures for young people. Faraday's six "Chemical History of a Candle" lectures began as a Christmas series in 1848-49; he delivered that popular series again in 1854-55 and 1860-61. In 1861 the lectures were published as a small book, arguably the most popular science book of all time. Since its publication, it has hardly been out of print in English and has been translated into more than a dozen languages, including French, Polish, and Japanese. ${ }^{9}$ The Christmas Lectures series was the first science program to be broadcast on the BBC's fledgling television service in 1937. Since 1966 they have been televised annually and now reach an audience of millions.

\section{After Faraday}

None of Davy's or Faraday's work in research, lecturing, or advice would have been possible without access to the Royal Institution's laboratory. Until the 1870s, when the Cavendish Laboratory at Cambridge and the Clarendon Laboratory at Oxford were established, the Royal Institution arguably had the best-equipped laboratory in Britain and one of the best in Europe. After Faraday retired, however, researchers at the institution, rather than attempting to cover virtually all of the physical sciences, increasingly concentrated their efforts on specific physical or chemical topics.

The beginnings of that process can be seen in the work of Faraday's successor John Tyndall (ca. 1822-93; see figure 4). ${ }^{10}$ After studying under Robert Bunsen at Marburg University, where he received his doctorate in 1850 , Tyndall took a strong interest in magnetism, which had attracted Faraday's attention. In 1853 Tyndall delivered a highly successful Friday Evening Discourse that led to his appointment, at Faraday's suggestion, as professor of natural philosophy. Following Faraday's death, Tyndall succeeded his mentor as superintendent of the house. Tyndall's scientific work included showing why the sky is blue, establishing a theory of glaciers, and attacking theories of spontaneous generation. By today's standards, Tyndall's work would be seen as 


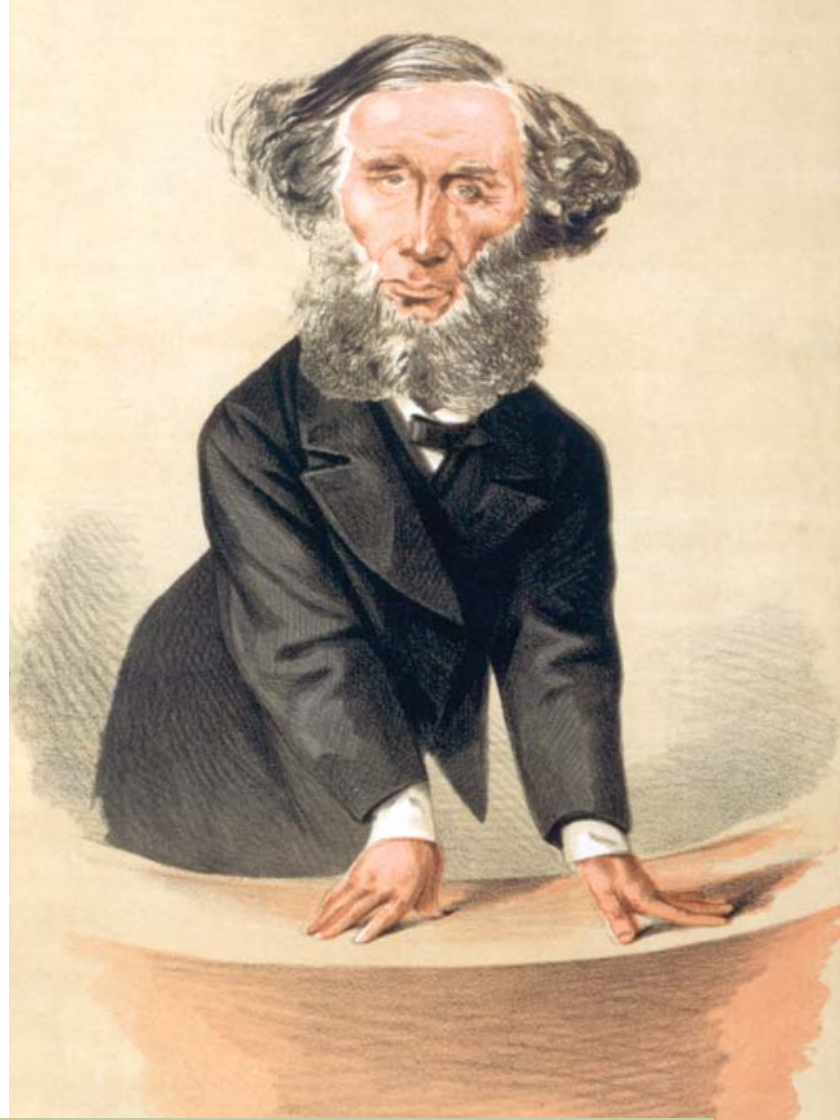

FIGURE 4. JOHN TYNDALL AS DEPICTED BY VANITY FAIR,

6 April 1872, page 110. (Courtesy of the Royal Institution.)

broad, but by the standards of Davy and Faraday, it was really quite focused on specific subjects.

To the general public Tyndall was most notable for his efforts to promote a naturalistic approach to scientific knowledge. He coined the phrase "the scientific use of the imagination," which Arthur Conan Doyle had Sherlock Holmes use in The Hound of the Baskervilles (1902). Tyndall delivered numerous lectures, including 12 series of Christmas Lectures, and wrote many books on popular scientific subjects to promote his views. In his presidential address to the Belfast meeting of the British Association for the Advancement of Science in 1874, Tyndall made the most famoussome would say notorious - statement of his view that the world should be studied from a naturalistic viewpoint rather than a theistic one. ${ }^{11}$

Tyndall retired as superintendent in 1887 and was replaced by James Dewar (1842-1923), who had been Fullerian Professor since $1877 .{ }^{12}$ Dewar's research was even more focused than Tyndall's, since he concentrated almost entirely on cryogenics. He invented the Dewar flask, popularly known outside science as the Thermos flask after the company that first used it for domestic purposes. In his efforts to reach a temperature low enough to liquefy hydrogen $-\mathrm{a}$ goal he achieved in 1898-Dewar constructed largescale apparatus, particularly pumps, in the Royal Institution's basement laboratory (see figure 5).

By the end of the 19th century, the practice of science was changing. Scientific research was beginning the transforma- tion from an activity undertaken by a single individual working in a laboratory, perhaps with an assistant, to the current situation in which the head of a laboratory is generally supported by a large staff of postdoctoral assistants and doctoral students. The subsequent development of the Royal Institution reflected those broad changes. Scientific research at the institution was given a massive boost in the 1890s when industrial chemist Ludwig Mond endowed the Davy-Faraday Research Laboratory (DFRL). The Prince of Wales, the future Edward VII, opened the DFRL in 1896.

\section{The 20th century}

Although it was highly innovative in its opening years - for example, it admitted women scientists, a rare policy at the timethe DFRL became moribund during and after the Great War. That was largely due to the aged Dewar refusing to let go; he died in office in 1923.

Dewar's replacement was Nobel Prize recipient William Henry Bragg (1862-1942). Bragg had been educated at Cambridge University and had then taught mathematics and physics at Adelaide University in South Australia, where his son, William Lawrence Bragg (1890-1971), was born. ${ }^{13}$ By 1904 the elder Bragg had commenced working on radioactivity, especially $\gamma$ rays, and on $x$ rays. In 1909 he returned to England as a professor of physics at Leeds University. ${ }^{14}$ In 1912 he and Lawrence, now a research student at the Cavendish Laboratory, worked out how to determine the structure of crystals using $\mathrm{x}$-ray diffraction patterns. For that work the Braggs jointly received the 1915 Nobel Prize in Physics. Lawrence received the news while serving as an officer in the sound-ranging units on the Western Front. At the age of 25 he remains the youngestever science Nobel Prize recipient.

Under William, the Royal Institution took on new vitality, restoring its place at the center of science communication and using new technologies such as wireless radio, cinema, and television. He also made the DFRL the world's most important laboratory for x-ray crystallography. He built up a formidable team of researchers, including John Desmond Bernal, William

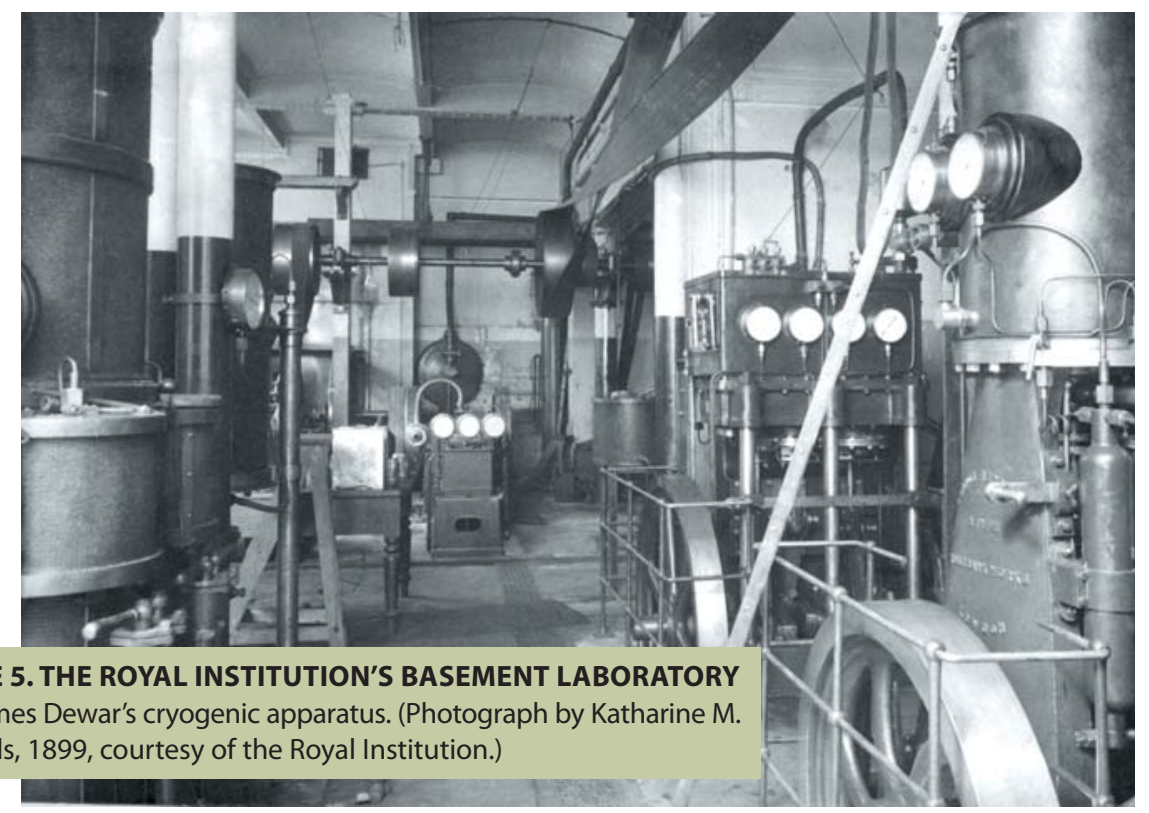


Thomas Astbury, and, briefly, the only British woman ever to receive the Nobel Prize for Chemistry, Dorothy Hodgkin. One member of Bragg's team, Kathleen Lonsdale, used x-ray crystallography to show that benzene, discovered by Faraday in 1825, was a hexagonal planar molecule. Lonsdale became the first woman elected a fellow of the Royal Society of London in 1945. The team structure of the DFRL in the 1920s proved to be an early example of what has since become the standard pattern for undertaking scientific research.

Following William Bragg's death in 1942, the DFRL had three directors, including the brain scientist Henry Dale, over the next 12 years. A serious period of institutional instability in the early 1950s ended when Lawrence Bragg took over in 1954. As director of the Cavendish Laboratory from 1938, Bragg had become well acquainted with C. P. Snow (1905-80), a physical chemist turned civil servant,

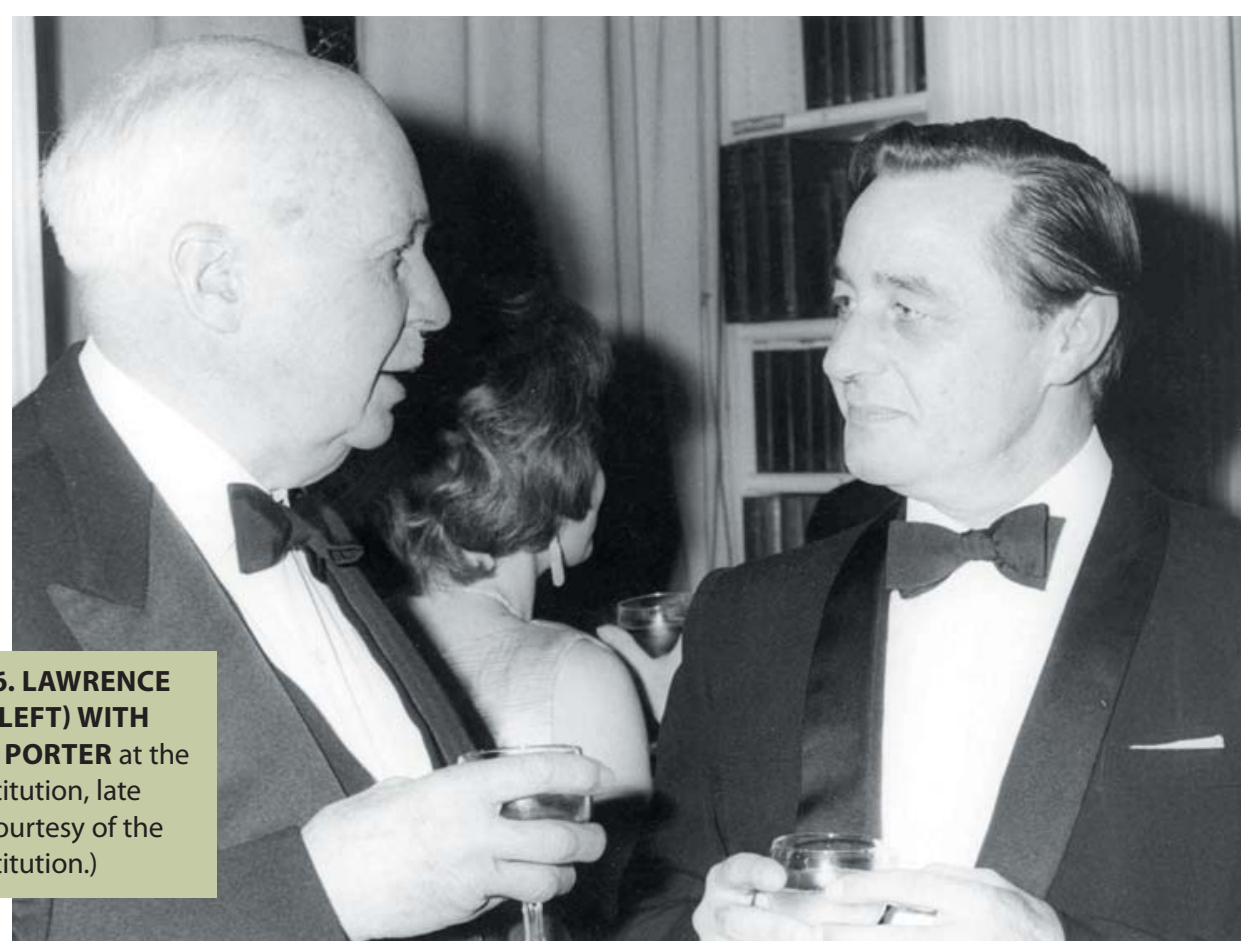
novelist, and pundit. There is some evidence that Bragg and Snow together coined the phrase "the two cultures" to denote what Snow saw as a yawning social and political gulf between scientists and what he termed literary intellectuals. ${ }^{15}$ Snow's Cambridge University Rede Lecture of the same title, delivered in 1959, sparked a major cultural debate in Britain that continues to this day.

Under Bragg, the Royal Institution became a major center for discussions about the relationships between science, culture, and society. Bragg revived the public programs, introduced school lectures, and laid the groundwork for the annual televising of the Christmas Lectures. At a televised Friday Evening Discourse, Snow outlined his "second look" at the issues surrounding the two cultures debate. In that lecture, he changed his test for scientific literacy from knowledge of the second law of thermodynamics to knowledge of molecular biology. That was doubtless the result of Bragg's influence; at the Cavendish, he had overseen the work of Francis Crick and James Watson on the double helical structure of DNA.

Bragg also continued his research, and under him the Royal Institution returned to $x$-ray crystallography, concentrating on the structure of proteins such as hemoglobin and myoglobin. Max Perutz and John Kendrew, who held joint appointments at the Royal Institution and the University of Cambridge, received the Nobel Prize in Chemistry for that work in 1962. In the 1960s the DFRL turned to the structure of enzymes. A group headed by David Phillips, including Louise Johnson, made the first determination of the structure of an enzyme, lysozyme. Little wonder then that Dale later wrote, "It is cheering to recognise the extent to which research in 'Molecular Biology', first at Cambridge and now at Oxford, will have been pioneered from the R.I." 16

Following Bragg's retirement in 1966, photochemist George Porter (1920-2002) became director of the Royal Institution and the DFRL (see figure 6). ${ }^{17}$ Like Bragg, Porter continued the institution's participation in the two-cultures debate, especially by ensuring that science was prominently represented on tele-

vision. For instance, Porter made a 10-part television series entitled The Laws of Disorder about thermodynamics. One can hardly imagine anything like that happening today.

Since Porter's retirement in 1985, the Royal Institution has had five directors. Demands in the research environment have meant that during the past 50 years or so the balance of the institution's activities has changed from being dominated by research to emphasizing scientific engagement with a wide variety of audiences of all age groups. The Royal Institution's vision is to inspire everyone to think more deeply about science and its place in our lives. That mission is particularly aided by the development of the institution's digital science channel, both on its website, www.rigb.org, and on YouTube.

\section{Legacy}

The Royal Institution has had a profound effect on the history of science, not only because of the scientific knowledge produced in its laboratories but also because of the way its success has been emulated, most spectacularly in the founding of the US Smithsonian Institution. James Smithson (1764-1829), a biological son of the 1st Duke of Northumberland, was an early Royal Institution proprietor. ${ }^{18} \mathrm{He}$ bequeathed his fortune of $\$ 508318.46$ to "the United States of America, to found at Washington, under the name of the Smithsonian Institution, an Establishment for the increase \& diffusion of knowledge among men," a statement clearly influenced by the Royal Institution's founding aims.

When Smithson's money arrived in the US in 1835, Congress debated for some years over how to implement the terms of the will. They even asked Faraday to inquire what Smithson's role had been at the Royal Institution. With Faraday's strong support, Joseph Henry (1797-1878) was appointed the Smithsonian's first secretary in 1846. At Henry's request, Faraday provided details of the Royal Institution's activities and its physical layout. Although the Smithsonian Institution followed a very different path from that of the Royal Institution-a 
reflection of the different scientific needs of the US and Britain-both organizations were inspired by the same belief in the cultural and practical value of scientific knowledge.

From improving safety in coal mines, to laying the theoretical foundations of the practical use of electricity, to the improvement of picnics and the understanding of enzyme action, to inspiring other institutions, the Royal Institution has left its mark. During its existence, it has always taken full advantage of the latest media to communicate science to as wide an audience as possible-it was among the first to use mass print technology, film, wireless radio, television, and the Web to communicate science. There cannot be many buildings of 3000 square meters that have produced so many lasting legacies. Such is the effect of the science that has flowed, and continues to flow, from 21 Albemarle Street.

\section{REFERENCES}

1. F. A. J. L. James, ed., "The Common Purposes of Life": Science and Society at the Royal Institution of Great Britain, Ashgate (2002); F. A. J. L. James, A. Peers, Phys. Perspect. 9, 130 (2007).

2. Minutes of the Managers' Meetings 1799-1903, vol. 1, Royal Institution of Great Britain (1971), p. 1.

3. G. N. Cantor, Notes Rec. R. Soc. London 25, 87 (1970).

4. J. Z. Fullmer, Young Humphry Davy: The Making of an Experimental Chemist, American Philosophical Society (2000); D. Knight, Humphry Davy: Science and Power, Cambridge U. Press (1996); J. Golinski, The Experimental Self: Humphry Davy and the Making of a Man of Science, U. of Chicago Press (2016).

5. F. A. J. L. James, in Compound Histories: Materials, Governance and Production, 1760-1840, L. Roberts and S. Werrett, eds., Brill (2017), p. 269.
6. F. A. J. L. James, Trans. Newcomen Soc. 75, 175 (2005); Physis: Riv. Int. Stor. Sci. 29, 205 (1992).

7. G. Cantor, Michael Faraday: Sandemanian and Scientist; A Study of Science and Religion in the Nineteenth Century, MacMillan (1991); D. Gooding, F. A. J. L. James, eds., Faraday Rediscovered: Essays on the Life and Work of Michael Faraday, 1791-1867, Macmillan (1985); D. Gooding, Experiment and the Making of Meaning: Human Agency in Scientific Observation and Experiment, Kluwer Academic (1990); F. A. J. L. James, Michael Faraday: A Very Short Introduction, Oxford U. Press (2010); F. A. J. L. James, ed., The Correspondence of Michael Faraday, 6 vols., Institution of Engineering and Technology (1991-2012).

8. F. A. J. L. James, Trans. Newcomen Soc. 70, 153 (1999); F. A. J. L. James, M. Ray, Hist. Technol. 15, 213 (1998).

9. M. Faraday, The Chemical History of a Candle: Sesquicentenary Edition, with a facsimile reproduction of Faraday's manuscript lecture notes from Royal Institution MS F4 J21, F. A. J. L. James, ed., Oxford U. Press (2011).

10. R. Jackson, The Ascent of John Tyndall: Victorian Scientist, Mountaineer, and Public Intellectual, Oxford U. Press (2018); J. Elwick, R. Jackson, B. Lightman, M. Reidy, eds., The Correspondence of John Tyndall, U. of Pittsburgh Press (2016- ).

11. R. Barton, Osiris 3, 111 (1987).

12. J. Rowlinson, Sir James Dewar, 1842-1923: A Ruthless Chemist, Ashgate (2012).

13. J. Jenkin, William and Lawrence Bragg, Father and Son: The Most Extraordinary Collaboration in Science, Oxford U. Press (2008); A. M. Glazer, P. Thomson, eds., Crystal Clear: The Autobiographies of Sir Lawrence and Lady Bragg, Oxford U. Press (2015).

14. R. Stuewer, Br. J. Hist. Sci. 5, 258 (1971).

15. R. Cole, Interdiscip. Sci. Rev. 41, 133 (2016).

16. H. Dale to L. Bragg (31 January 1966), Papers of Sir Lawrence Bragg 1890-1971, box 11, G/97, archive collection, Royal Institution of Great Britain, London.

17. R. Cole, Notes Rec. R. Soc. London 69, 191 (2015).

18. H. Ewing, The Lost World of James Smithson: Science, Revolution, and the Birth of the Smithsonian, Bloomsbury (2007).

\section{INDUSTRIAL PHYSICS FORUM}

\author{
on fabrication, imaging, and sensing in biological systems
}

\section{OCTOBER 22-24, 2018}

Long Beach Convention Center, Long Beach, CA

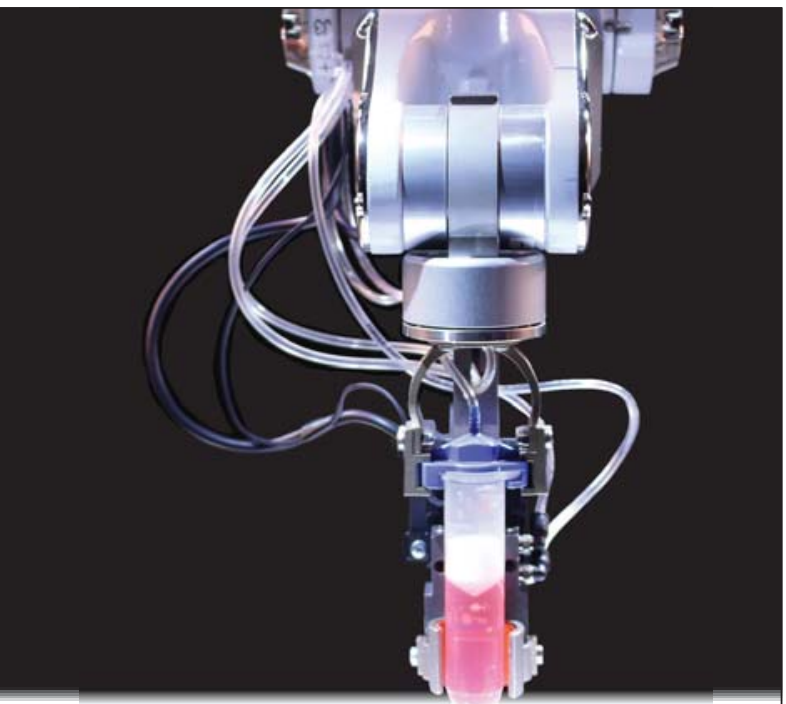

www.avs.org/symposium/

Sponsored by the American Institute of Physics and held at the AVS 65th International Symposium \& Exhibition
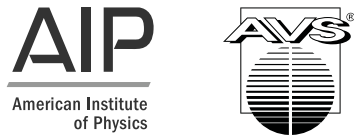